\section{M \\ VIA MEDICA www.fr.viamedica.pl}

\title{
Erectile dysfunctions in patients with systemic sclerosis
}

\section{ABSTRACT}

Erectile dysfunctions are a common feature in patients with systemic sclerosis. They are resulted from a complex pathomechanism. The main role is attributed to vascular alterations and fibrosis of the carvernous bodies. Depression and disturbed autonomy nervous system function may be additional factors for development of erectile dysfunctions. Diagnosis is based on subjective patient's data and functional tests. Treatment of erectile dysfunctions in scleroderma patients is difficult, multifactorial and sometimes ineffective.

Forum Reumatol. 2019, tom 5, nr 3: 118-123

Key words: systemic sclerosis; erectile dysfunctions; impotence

\section{INTRODUCTION}

Systemic sclerosis ( $\mathrm{SSc}$ ) is a systemic disease of the connective tissue characterized by vascular changes, occurrence of autoimmunization phenomena and generalized fibrosis of internal organs and skin [1, 2]. The disease is of progressive nature, and it leads to serious complications, even though its course in particular patients may be quite diverse. Due to the fact that it spreads to all systems and organs, the disease frequently requires cooperation of many specialists who work under the direction of a rheumatologist. Sexual function disorders, including erectile dysfunction, that occur in the patients are often overlooked by physicians due to more severe cardiopulmonary or renal changes [3]. On the one hand, it results from diversification and advancement of multiple organ involvement, which often pose significant threat to life, and, on the other hand, from the intimate nature of erectile dysfunction, and the fact that rheumatologists are less acquainted with these issues. The aim of the paper is to discuss the aforementioned problems.

\section{DEFINITION AND PATHOGENESIS OF ERECTILE DYSFUNCTION}

The term erectile dysfunction applies to functional and morphological changes that preclude getting and maintaining erection in an extent that would enable the patient to reach sexual satisfaction [4]. Changes occurring for at least 6 months are considered to be an abnormal state, namely erectile dysfunction [5].

Penis erection requires synergy of several phenomena. They include increased inflow of arterial blood controlled by the nervous system. The process may be directly linked to sexual arousal. Another necessary phenomenon is relaxation of the smooth muscles of the phallic cavernous bodies, and the last element that leads to the occurrence and maintenance of erection is decrease in or periodical cut-off of venous blood outflow from the phallus [6]. Structural changes, primarily penile fibrosis, can be an additional factor that influences the occurrence of erectile dysfunction. The ability to get an erection is also controlled by hormones, and is associated with the development and maturation of the reproductive organs - phenomena controlled by the hormonal system. 
In pathogenesis of vascular changes leading to erectile dysfunction close attention is paid to endothelial cells. It is assumed that their damage and dysfunction are a common mechanism of vascular damage in all vasculopathies observed in patients suffering from SSc [7, 8]. Endothelial cells line small resistance arteries that supply the cavernous bodies with blood. A layer of vascular muscle cells is located under the layer of endothelial cells. Impaired function of the endothelium leads to muscle membrane hyperplasia and severely damages blood vessels. Excessive expression of multiple adhesion particles occurs in the endothelium. As a result, some cells can pass through the endothelium and perivascular inflammatory infiltrations may occur. Component activities of the endothelium, such as production of agents that dilate vessels (for example nitrogen oxide) are impaired, and selection of vasocontricting agents (for example endothelin-1) as well as expression of adhesion proteins (for example selectin, integrin) are changed. Distorted mutual composition of the agents produced by the endothelium, and the substances produced by the cells passing through the vascular wall can stimulate proliferation of the smooth muscle cells of tunica media of the vessel, and their migration in the direction of the endothelium [9].

These phenomena were described as components of the development of main vascular changes observed in patients with SSc, such as the Raynaud's symptom, ulceration of fingertips, pulmonary arterial hypertension, and erectile dysfunction. These changes are almost always accompanied by changes in microcirculation, which are detected during, inter alia, capillaroscopy.

Another - lesser known - factor responsible for erectile dysfunction is fibrosis of phallic cavernous bodies [6]. In patients with SSc the autonomous system becomes impaired. This type of neuropathy can also contribute to the development of erectile dysfunction [10]. The role of depression and fear as factors impairing erection should also not be forgotten $[11,12]$.

\section{OCCURRENCE OF ERECTILE DYSFUNCTION IN PATIENTS WITH SYSTEMIC SCLEROSIS}

Erectile dysfunction is a relatively frequent change observed in contemporary men. Statistical data do not include short-term or periodical dysfunctions, only those that last continuously for at least six months, in accordance with the previously provided definition.
The association between the incidence of erectile dysfunction and age is commonly known. Thus, among males under 40 years of age the ailment occurs in only 1 to $10 \%$ of individuals, in males aged 60-69 - the incidence of the discussed disorder increases to $20-40 \%$, and in males aged 70 and 80 - it reaches up to $100 \%$ [13].

There are many factors known to influence erectile dysfunction, such as diabetes, hyperlipidaemia, hypertension, prostate hypertrophy, urinary tract infections and depression. The most common factors include alcohol consumption and smoking as well as obesity [1]. Most of these conditions increase development of atherosclerosis, also in the arterial vessels that supply the cavernous bodies with blood. The correlation between erectile dysfunctions and the risk of ischemic heart disease development has even been proven $[15,16]$.

In patients with $\mathrm{SSc}$ erectile dysfunction occurs without the development of atherosclerotic changes. In older patients as well as those in whom SSc has been present for a relatively long amount of time, certain aggravation of atherosclerosis is found [16, 17]. Regardless of the complexity of the phenomenon, changed endothelium and fibrosis are responsible for the so-called sclerodermic penis. However, knowledge of other factors that influence erectile dysfunction is necessary for planning detected during, inter alia, via eliminating the modifiable risk factors.

Erectile dysfunction was described for the first time in patients with SSc in 1981 by Lally and Jimenez [18]. They described 5 patients with SSc in whom impotence was the first symptom of the disease. In the following years, several publications indicating frequent occurrence of erectile dysfunction in patients with the discussed disease were published [19, 20]. Most of them, however, concerned small populations of patients; $\mathrm{SSc}$ is a rare disease and men constitute a small percentage of patients (approximately 6.7 women per 1 man) [21]. All these publications show large percentage of patients suffering from SSc affected by erectile dysfunction (up to $83 \%$ ). The largest study is the paper by Foocharoen et al. [22] carried out within the framework of the EURSTAR group. Among 130 men with SSc who were examined, only $17.7 \%$ had unchanged erectile function Severe erectile dysfunction was observed in $30.8 \%$ of the examined patients. The intensity of erectile changes was assessed using the International Index of 
Erectile Function-5 - a survey characterized by sensitivity and specificity of erectile dysfunction detection [22]. The gathered patients were subjected to an analysis which considered concomitance of other diseases (for example systemic hypertension, diabetes, smoking as well as depression, hyperprolactinemia and excessive alcohol consumption). It was proven that some comorbidities and consumption of certain drugs significantly increase the probability of erectile dysfunction, and, in general, the higher the number of comorbidities, the higher the risk of occurrence of the discussed dysfunctions.

It is also interesting to show the correlation between the occurrence of erectile dysfunction and some of the symptoms or lesions found in patients belonging to the typical clinical picture of SSc. The dependence of erectile dysfunction occurrence on the intensity of skin lesions, decrease in increased respiratory capacity below $80 \%$ of the normal values, occurrence of hypertension in the pulmonary artery (above $40 \mathrm{~mm} \mathrm{Hg}$ ), occurrence of renal crisis and high activity of the disease has been proven. No association between erectile dysfunction and the occurrence of anti-topoisomerase I antibodies (Scl-70) was found, however, such association was observed in the case of anti-centromere antibodies and anti-RNA polymerase III antibodies. The form of the disease (limited, generalized), duration time of evident disease measured from the moment of Raynaud's symptom occurrence, as well as other symptoms, such as finger ulceration, tendon friction rubs, swallowing disorders or lung fibrosis in imaging were not related to erectile dysfunction. Severity of erectile dysfunction in patients with SSc is significant. In the aforementioned International Index of Erectile Dysfunctions, the maximum amount of points that indicates lack of dysfunction is 25 . In the discussed study, the median in 130 patients with SSc is 13, which corresponds with moderate dysfunction. By comparison, in a similar age group of general population the average result was 22 [23], and only $1.3 \%$ of males suffer from severe erectile dysfunction. It was also demonstrated that in patients with SSc erectile dysfunction was more common than in a comparable group of patients with rheumatoid arthritis [24].

In general, examination of 130 patients showed that despite varied clinical image and course of SSc, higher activity of the disease and its intensified course promote erectile dysfunction. Due to small number of patients during breakdown into subgroups, despite the observed tendency of the changes, no statistical significance enabling drawing unambiguous conclusions was acquired. It was so in the case of duration time of Raynaud's symptom. Despite these shortcomings, this most comprehensive study on the discussed issues demonstrates that erectile dysfunction seems to be associated with other symptoms and changes resulting from the development of vascular disorders.

\section{FUNCTIONAL TESTS OF THE VASCULAR SYSTEM IN PATIENTS WITH SYSTEMIC SCLEROSIS AND ERECTILE DYSFUNCTION}

The evaluation of erectile dysfunction is based on the patient's subjective sensations, but often requires additional laboratory tests. Functional tests may concern directly the penile condition or be a general assessment of the condition of the patient's vessels.

The vascular system involvement may manifest itself as pulmonary arterial hypertension which correlates with erectile dysfunction [22]. Similarly, a positive correlation was found between penile blood flow disorders, as well as finger and kidney arteries [25-27]. Similarly, the correlation between changes in the microcirculation detected by capillaroscopy and the erectile dysfunction was demonstrated, but the detection of capillaroscopic changes did not allow to predict the occurrence of erectile dysfunction [28].

The most frequently performed test is ultrasound examination of blood circulation in cavernous bodies. The thermographic temperature of the phallic skin is also examined $[29,30]$. It is possible to evaluate the changes in the penile circumference at the base and the glans. In this examination, which can be performed 24 hours a day, the patient staying at home is assessed for night and morning erection, regardless of sexual arousal. The evaluation of erection after prostaglandin $\mathrm{E}_{1}$ injection is of invasive character. It is also used before determining the possible correlations of the penis shape changed by fibrosis. A penile arteriography is rarely performed [4].

Gigante et al. [31] demonstrated abnormal vascular endothelial growth factor (VEGF) to endostatin ratio in patients with SSc and erectile dysfunction, thus suggesting the role of angiogenesis regulation in the pathogenesis of this disease (similarly to other 
inflammatory rheumatic diseases) [32]. So far, this study has not been applied in clinical practice.

\section{DIAGNOSTIC MANAGEMENT OF PATIENTS WITH SYSTEMIC SCLEROSIS AND ERECTILE DYSFUNCTION}

Medical treatment of SSc and erectile dysfunction is extremely complex. It must cover the following groups of issues: (1) a set of general examinations resulting from a primary disease; (2) assessment of erectile dysfunction; (3) assessment of other diseases or risk factors that may affect the degree of vasculopathy development.

In most cases, a patient with erectile dysfunction already has a complete set of examinations allowing to diagnose and evaluate the stage of organ changes, including those directly related to vascular involvement. It is essential to become acquainted with these results and to perform the examinations that have not been conducted or which are outdated.

The rheumatologist should gain the trust of the patient in order to collect a reasonably complete history of erectile dysfunction. This is connected with the history and examination of concomitant diseases. It is assumed that the main factors responsible for the development of erectile dysfunction in patients with SSc are vascular changes and fibrosis, and depression only to a small extent, but other atypical or non-SSc-related diseases or changes influencing the occurrence of erectile dysfunction cannot be a priori rejected in case of a specific patient. These include neurological changes, both peripheral and central, states after injuries or developmental disorders of the spine, demyelinating diseases (some of which may accompany autoimmune diseases).

Hormonal imbalances in SSc patients were not described as the cause of erectile dysfunction. In order to fully assess the patient's condition, it is advisable to evaluate whether secondary hypogonadism or other hormonal imbalances have occurred. Hyperprolactinemia is a common phenomenon in autoimmune diseases and has been described in SSc patients [33]. Hypothyroidism is common in SSc, but it is not always diagnosed.

A number of diseases (including metabolic diseases) that may cause or exacerbate erectile dysfunction have been mentioned earlier [34]. Tobacco smoking (exceptionally harmful due to vasoconstriction in SSc patients) and alcohol consumption are a common cause of erectile dysfunction in both the general population and in SSc patients.

A great number of drugs may impair sexual function and this should be taken into account when evaluating the patients. Thiazide diuretics, spironolactones, $\beta$-adrenolytics, $\mathrm{H}_{2}$ receptor antagonists, some antidepressants and cyclophosphamide are the examples of such drugs.

It is also necessary to take into account the age of the patient, which in the general population is associated with a decrease in erection efficacy of the penis. This is connected with atherosclerotic changes and relatively well described factors influencing their development. The urinary tract assessment is necessary. Lower urinary tract symptoms such as the signs of overactive bladder, urinary incontinence and dysuria often accompany erectile dysfunction in SSc patients [35].

In the final stage of the examination, the rheumatologist attending a patient with SSc and erectile dysfunction should consider feasible vascular examinations (unless these have been performed as part of the general diagnosis of the disease), such as an ultrasound evaluation of blood circulation in the phallus.

\section{TREATMENT}

Erectile dysfunction treatment in SSc patients is difficult and often ineffective. There is also relatively little research on the issue. The initial approach is based on the analysis and elimination or correction of all modifiable factors from the lifestyle, co-morbidities and medications taken.

Erectile dysfunction pharmacotherapy is based on the use of phosphodiesterase-5 inhibitors. These drugs increase the concentration of cGMP, which is conductive to the relaxation of smooth muscles by facilitating blood flow to cavernous bodies. These drugs facilitate erection, but do not create it, sexual stimulation is necessary. There are several drugs available in this group that differ in duration of action, although their efficacy is assumed to be similar. The use of phosphodiesterase-5 inhibitors in patients with SSc was the subject of single studies only. The research revealed that continuous administration of the drug is more effective than on-demand administration [4]. Continuous administration is associated with improvement of objective penile blood supply and endothelial status indicators [36]. Tada- 
lafil was also suggested to be more effective than sildenafil [12]. Interestingly, phosphodiesterase-5 inhibitors are used in SSc patients to treat pulmonary hypertension. The extent to which erectile dysfunction is reduced in these patients is not known.

It is technically more difficult to administer prostacyclin derivatives. These drugs are injected into cavernous bodies. There are also attempts to use prostacyclin analogues in the form of intraurethral insert or topical drug administration in the form of ointment [37].

For patients in whom these drugs are not effective, vacuum pumps inducing blood flow to cavernous bodies are recommended. They are quite commonly used in patients with erectile dysfunction due to other reasons (e.g. diabetes).

Inflatable cavernous prosthesis is rarely implanted in SSc patients. It results from the fact that their implantation requires the excision of fibrous tissues, which may prove to be a technically difficult procedure [4].

The attempts to administer the regenerative therapy of cavernous vascular endothelium, as well as mesenchymal, stem and fat cell transplantation should be mentioned. Another search for a solution consists in a gene therapy, aimed at nitric oxide endothelial cells or vascular endothelial growth factor (VEGF). These works have not yet exceeded the experimental stage [38].

\section{SUMMARY}

Erectile dysfunction in patients with SSc is still not well known, except for the fact that they occur frequently. As mentioned above, this is a consequence of the relatively rare diagnosis of SSc in men, as well as the fact that this issue is omitted when obtaining the patient's history. This may result from insufficient preparation of the rheumatologist for the analysis of sexual issues. Erectile dysfunction is not a life-threatening factor itself, but often correlates with the development of other vascular changes. However, it is of great importance for the quality of patients' lives, especially as the symptoms are most often displayed from the beginning of a clinically manifested disease. Despite the limited therapeutic possibilities, it seems important to broaden the knowledge of the subject, which in some cases will help patients and will always make the rheumatologist's actions more complete and more patientthan disease-oriented.

\section{References}

1. Denton CP, Khanna D. Systemic sclerosis. Lancet. 2017; 390(10103): 1685-1699, doi: 10.1016/S01406736(17)30933-9, indexed in Pubmed: 28413064.

2. Kowal-Bielecka O, Bielecki M. Twardzina układowa. In: Puszczewicz M. ed. Wielka Interna. Reumatologia, wyd. II. Medical Tribune, Warszawa 2016: 136-150.

3. Kucharz EJ. Reumatoseksuologia: wprowadzenie do problematyki interdyscyplinarnej. Reumatologia. 2010; 48: 155-158.

4. Bruni C, Raja J, Denton CP, et al. The clinical relevance of sexual dysfunction in systemic sclerosis. Autoimmun Rev. 2015; 14(12): 1111-1115, doi: 10.1016/j.autrev.2015.07.016, indexed in Pubmed: 26235995.

5. Grant P, Jackson G, Baig I, et al. Erectile dysfunction in general medicine. Clin Med (Lond). 2013; 13(2): 136-140, doi: 10.7861/clinmedicine.13-2-136, indexed in Pubmed: 23681859.

6. Lally EV, Burnett AL, Bivalacqua TJ. Erectile dysfunctions. In: Varga J, Denton CP, Wigley FM. ed. Scleroderma: from pathogenesis to comprehensive management. Springer, New York 2012: 395-398.

7. Bivalacqua TJ, Usta MF, Champion HC, et al. Endothelial dysfunction in erectile dysfunction: role of the endothelin in scleroderma and rheumatoid arthritis. J Rheumatol. 2004; 31: 508-513.

8. Nehra A, Hall SJ, Basile G, et al. Systemic sclerosis and impotence: a clinicopathological correlation. J Urol. 1995; 153(4): 1140-1146, indexed in Pubmed: 7869483.
9. Manetti M, Romano E, Rosa I, et al. Endothelial-to-mesenchymal transition contributes to endothelial dysfunction and dermal fibrosis in systemic sclerosis. Ann Rheum Dis. 2017; 76(5): 924-934, doi: 10.1136/annrheumdis-2016-210229, indexed in Pubmed: 28062404.

10. Dessein PH, Joffe BI, Metz RM, et al. Autonomic dysfunction in systemic sclerosis: sympathetic overactivity and instability. Am J Med. 1992; 93(2): 143-150, doi: 10.1016/00029343(92)90043-b, indexed in Pubmed: 1497010.

11. Straszecka J, Kucharz EJ, Jonderko G, et al. Depression and anxiety in patients with systemic sclerosis. Clin Rheumatol. 1996; 15(6): 621, doi: 10.1007/bf02238557, indexed in Pubmed: 8973877.

12. Ostojic P, Damjanov N. The impact of depression, microvasculopathy, and fibrosis on development of erectile dysfunction in men with systemic sclerosis. Clin Rheumatol. 2007; 26(10): 1671-1674, doi: 10.1007/s10067-0070567-4, indexed in Pubmed: 17294050.

13. Lewis RW, Fugl-Meyer KS, Corona G, et al. Definitions/epidemiology/risk factors for sexual dysfunction. J Sex Med. 2010; 7 (4 Pt 2): 1598-1607, doi: 10.1111/j.1743-6109.2010.01778.x, indexed in Pubmed: 20388160.

14. Jaeger VK, Walker UA. Erectile Dysfunction in Systemic Sclerosis. Curr Rheumatol Rep. 2016; 18(8): 49, doi: 10.1007/s11926-016-0597-5, indexed in Pubmed: 27402106.

15. Inman BA, Sauver JL, Jacobson DJ, et al. A population-based, longitudinal study of erectile dysfunction and future 
coronary artery disease. Mayo Clin Proc. 2009; 84(2): 108-113, doi: 10.4065/84.2.108, indexed in Pubmed: 19181643.

16. Thompson IM, Tangen CM, Goodman PJ, et al. Erectile dysfunction and subsequent cardiovascular disease. JAMA. 2005; 294(23): 2996-3002, doi: 10.1001/jama.294.23.2996, indexed in Pubmed: 16414947.

17. Sedky Abdou MM, El Desouky SM, Helmy El Kaffas KM, et al. Premature atherosclerosis in systemic sclerosis patients: Its relation to disease parameters and to traditional risk factors. Int J Rheum Dis. 2017; 20(3): 383-389, doi: 10.1111/1756-185X.12987, indexed in Pubmed: 28036158.

18. Lally EV, Jimenez SA. Impotence in progressively systemic sclerosis. Ann Intern Med. 1981; 95(2): 150-153, doi: 10.7326/0003-4819-95-2-150, indexed in Pubmed: 6789736.

19. Nowlin NS, Brick JE, Weaver DJ, et al. Impotence in scleroderma. Ann Intern Med. 1986; 104(6): 794-798, doi: 10.7326/0003-4819-104-6-794, indexed in Pubmed: 3706932.

20. Hong P, Pope JE, Ouimet JM, et al. Erectile dysfunction associated with scleroderma: a case-control study of men with scleroderma and rheumatoid arthritis. J Rheumatol. 2004; 31(3): 508-513, indexed in Pubmed: 14994396.

21. Fransen J, Inanc M. Epidemiology. In: Hachulla E, Czirják L. ed. EULAR Textbook on systemic sclerosis. BMJ, London 2013: 28-37.

22. Foocharoen $C$, Tyndall A, Hachulla E, et al. Erectile dysfunction is frequent in systemic sclerosis and associated with severe disease: a study of the EULAR Scleroderma Trial and Research group. Arthritis Res Ther. 2012; 14(1): R37, doi: 10.1186/ar3748, indexed in Pubmed: 22348608.

23. Ponholzer A, Temml C, Mock K, et al. Prevalence and risk factors for erectile dysfunction in 2869 men using a validated questionnaire. Eur Urol. 2005; 47(1): 80-5; discussion 85, doi: 10.1016/j.eururo.2004.08.017, indexed in Pubmed: 15582253.

24. Horimoto AM, da Costa IP. Overlap between systemic sclerosis and rheumatoid arthritis: a distinct clinical entity? Rev Bras Reumatol Engl Ed. 2016; 56(4): 287-298, doi: 10.1016/j.rbre.2014.12.011, indexed in Pubmed: 27476621.

25. Rosato E, Barbano B, Gigante A, et al. Doppler ultrasound study of penis in men with systemic sclerosis: a correlation with Doppler indices of renal and digital arteries. Int J Immunopathol Pharmacol. 2013; 26(4): 1007-1011, doi: 10.1177/039463201302600422, indexed in Pubmed: 24355239.

26. Aversa A, Proietti M, Bruzziches R, et al. The penile vasculature in systemic sclerosis: A duplex ultrasound study. J Sex Med. 2006; 3(3): 554-558, doi: 10.1111/j.1743-6109.2005.00169.x, indexed in Pubmed: 16681482.
27. Rosato E, Aversa A, Molinaro I, et al. Erectile dysfunction of sclerodermic patients correlates with digital vascular damage. Eur J Intern Med. 2011; 22(3): 318-321, doi: 10.1016/j.ejim.2010.09.013, indexed in Pubmed: 21570655.

28. Keck AD, Foocharoen C, Rosato E, et al. Nailfold capillary abnormalities in erectile dysfunction of systemic sclerosis: a EUSTAR group analysis. Rheumatology (Oxford). 2014; 53(4): 639-643, doi: 10.1093/rheumatology/ket392, indexed in Pubmed: 24310296.

29. Aversa $A$, Bruzziches $R$, Francomano D, et al. Penile invoIvement in Systemic Sclerosis: New Diagnostic and Therapeutic Aspects. Int J Rheumatol. 2010; 2010: 708067, doi: 10.1155/2010/708067, indexed in Pubmed: 20981315.

30. Merla A, Romani GL, Tangherlini A, et al. Penile cutaneous temperature in systemic sclerosis: a thermal imaging study. Int J Immunopathol Pharmacol. 2007; 20(1): 139-144, doi: 10.1177/039463200702000116, indexed in Pubmed: 17346437.

31. Gigante A, Navarini L, Margiotta D, et al. Erectile dysfunction: Imbalance between pro-angiogenic and anti-angiogenic factors in systemic sclerosis. Eur J Intern Med. 2018; 53: e17-e18, doi: 10.1016/j.ejim.2018.04.017, indexed in Pubmed: 29699724.

32. Kucharz EJ, Kotulska A. Patofizjologiczna rola endostatyny w chorobach nienowotworowych. Pol Arch Med Wewn. 2006; 11: 507-511.

33. Kucharz EJ, Jarczyk R, Jonderko G, et al. High serum level of prolactin in patients with systemic sclerosis. Clin Rheumatol. 1996; 15(3): 314, doi: 10.1007/bf02229718, indexed in Pubmed: 8793271.

34. Kucharz EJ. Thyroid disorders in patients with progressive systemic sclerosis: a review. Clin Rheumatol. 1993; 12(2): 159-161, doi: 10.1007/bf02231519, indexed in Pubmed: 8358971.

35. Sanchez K, Denys P, Giuliano F, et al. Systemic sclerosis: Sexual dysfunction and lower urinary tract symptoms in 73 patients. Presse Med. 2016; 45(4 Pt 1): e79-e89, doi: 10.1016/j.Ipm.2015.08.009, indexed in Pubmed: 27016850

36. Proietti M, Aversa A, Letizia C, et al. Erectile dysfunction in systemic sclerosis: effects of longterm inhibition of phosphodiesterase type- 5 on erectile function and plasma endothelin-1 levels. J Rheumatol. 2007; 34(8): 1712-1717, indexed in Pubmed: 17611982.

37. Hanchanale V, Eardley I. Alprostadil for the treatment of impotence. Expert Opin Pharmacother. 2014; 15(3): 421-428, doi: 10.1517/14656566.2014.873789, indexed in Pubmed: 24369066.

38. Condorelli RA, Calogero AE, Vicari E, et al. Vascular regenerative therapies for the treatment of erectile dysfunction: current approaches. Andrology. 2013; 1(4): 533-540, doi: 10.1111/j.2047-2927.2013.00087.x, indexed in Pubmed: 23658196 . 


\section{$\mathbf{V M}$ \\ VIA MEDICA \\ www.fr.viamedica.pl}

Monika Chrzanowska, Eugeniusz Józef Kucharz

Katedra i Klinika Chorób Wewnętrznych, Reumatologii i Immunologii Klinicznej Śląskiego Uniwersytetu Medycznego w Katowicach

\section{Zaburzenia erekcicji u chorych na twardzinę ukł'aldowa}

Artykuł jest tłumaczeniem pracy: Chrzanowska M., Kucharz E.J., Erectile dysfunctions in patients with systemic sclerosis. Forum Reumatol. 2019 tom 5, nr 3: 118-123.

Należy cytować wersję pierwotną.

Piśmiennictwo znajduje się na stronach 122-123.

\section{STRESZCZENIE}

Zaburzenia erekcji występują często u chorych na twardzinę układową. Mają złożony patomechanizm. Najważniejszą rolę przypisuje się zmianom naczyniowym oraz włóknieniu ciał jamistych. Dodatkowymi czynnikami mogą być depresja i zaburzenia układu autonomicznego. W rozpoznaniu przede wszystkim należy pamiętać o zaburzeniach erekcji i zebrać dane subiektywne oraz dokonać badań czynnościowych. Leczenie zaburzeń erekcji u chorych na twardzinę układową jest trudne, wieloczynnikowe i nie zawsze skuteczne.

Forum Reumatol. 2019, tom 5, nr 3: 124-128

Słowa kluczowe: twardzina układowa; zaburzenia erekcji; impotencja

\section{WSTĘP}

Twardzina układowa (SSc, systemic sclerosis) jest układową, chorobą tkanki łącznej cechującą się zmianami naczyniowymi, występowaniem zjawisk autoimmunizacyjnych oraz uogólnionym włóknieniem narządów wewnętrznych i skóry $[1,2]$. Twardzina układowa jest chorobą postępującą, prowadzącą do poważnych powikłań, chociaż jej przebieg u poszczególnych chorych może być bardzo zróżnicowany. Choroba obejmuje wszystkie układy i narządy organizmu, co sprawia, że jej leczenie wymaga często współdziałania wielu specjalistów, działających pod kierunkiem reumatologa. Występujące u chorych zaburzenia czynności seksualnych, w tym zaburzenia erekcji, są często pomijane w praktyce lekarskiej $\mathrm{w}$ zestawieniu $\mathrm{z}$ poważnymi zmianami sercowo-płucnymi lub nerkowymi [3]. Wynika to $\mathrm{z}$ jednej strony $\mathrm{z}$ różnorodności i zaawansowania zajęcia procesem chorobowym wielu narządów, często istotnie zagrażających życiu, a z drugiej strony z intymnego charakteru zaburzeń erekcji oraz mniejszej znajomości tych zagadnień przez reumatologa. Omówienie tych problemów jest celem przedstawionej pracy.

\section{DEFINICJA I PATOGENEZA ZABURZEN EREKCJI}

Zaburzeniami erekcji określa się zmiany czynnościowo-morfologiczne uniemożliwiające uzyskanie lub utrzymanie wzwodu członka w stopniu zapewniającym uzyskanie satysfakcji seksualnej [4]. Za nieprawidłowy stan, czyli zaburzenia erekcji, uważa się opisane zmiany występujące co najmniej przez 6 miesięcy [5].

Wzwód członka wymaga współdziałania kilku zjawisk. Należą do nich zwiększony napływ krwi tętniczej regulowany przez układ nerwowy. Proces ten może mieć bezpośredni związek z pobudzeniem seksualnym. Drugim niezbędnym zjawiskiem jest relaksacja mięśni gładkich ciał jamistych prącia, a ostatnim elementem prowadzącym do wystąpienia i utrzymania wzwodu jest zmniejszenie lub okresowe zamknięcie odpływu krwi żylnej z prącia [6]. Dodatkowym składnikiem wpływającym na powstanie zaburzeń erekcji mogą być zmiany strukturalne, przede wszystkim włóknienie prącia. Zdolność do wzwodu podlega także kontroli hormonalnej i pozostaje w związku z rozwojem i dojrzewaniem narządów rodnych, które to zjawiska są regulowane przez układ hormonalny. W patogenezie zmian naczynio- 
wych prowadzących do zaburzeń erekcji dużo uwagi przypisuje się komórkom śródbłonka. Przyjmuje się, że ich uszkodzenie i dysfunkcja jest wspólnym mechanizmem uszkodzenia naczyń we wszystkich waskulopatiach obserwowanych u chorych na SSc [7, 8]. Komórki śródbłonka wyścielają małe tętnice oporowe doprowadzające krew do ciał jamistych. Pod warstwą komórek śródbłonka znajduje się warstwa naczyniowych komórek mięśniowych. Zaburzona czynność śródbłonka prowadzi do rozrostu błony mięśniowej i istotnie uszkadza naczynia krwionośne. W śródbłonku dochodzi do nadmiernej ekspresji wielu cząsteczek adhezyjnych. Może to powodować przechodzenie niektórych komórek przez śródbłonek i rozwój wokół naczyniowych nacieków zapalnych. Upośledzeniu ulegają składowe czynności śródbłonka, takie jak wytwarzanie czynników rozszerzających naczynia (np. tlenku azotu), zmieniona jest selekcja czynników obkurczających naczynia (np. endoteliny-1), a także ekspresja białek adhezyjnych (np. selektyn, integryn). Zaburzony wzajemny skład czynników wytwarzanych przez śródbłonek oraz substancje wytwarzane przez przechodzące przez ścianę naczyniową komórki mogą stymulować proliferację komórek mięśni gładkich błony środkowej naczynia i ich migrację w stronę śródbłonka [9].

Zjawiska te opisano jako komponenty rozwoju głównych zmian naczyniowych obserwowanych u chorych na SSc, takich jak objaw Raynauda, owrzodzenia opuszek palców, tętnicze nadciśnienie płucne, a także zaburzenia erekcji. Zmianom tym prawie stale towarzyszą zmiany w mikrokrążeniu, między innymi wykrywane w badaniu kapilaroskopowym.

Innym czynnikiem, słabiej poznanym, odpowiadającym za zaburzenia erekcji jest włóknienie ciał jamistych prącia [6]. U chorych na SSc upośledzeniu ulega układ autonomiczny. Ta forma neuropatii może też współuczestniczyć w rozwoju zaburzeń erekcji [10]. Nie można też zapomnieć o roli depresji i lęku jako czynników upośledzających erekcję [11, 12].

\section{WYSTEPPOWANIE ZABURZEŃ EREKCJI U CHORYCH NA TWARDZINE UKŁADOWA}

Zaburzenia erekcji są stosunkowo częstą zmianą obserwowaną u współcześnie żyjących mężczyzn. W zestawieniach nie uwzględnia się krótkotrwałych lub okresowych zaburzeń, a jedynie, zgodnie z wcześniej podaną definicją, zaburzenia trwające bez przerwy co najmniej pół roku.
Powszechnie znany jest związek częstości występowania zaburzeń erekcji z wiekiem. I tak, wśród mężczyzn do 40. roku życia dolegliwość występuje tylko u około 1-10\% osób, w wieku 60-69 lat częstość występowania omawianego zaburzenia zwiększa się do 20-40\%, a u mężczyzn 70- i 80-letnich dochodzi do $100 \%$ [13].

Znanych jest wiele czynników wpływających na zaburzenia erekcji, takich jak: cukrzyca, hiperlipidemia, nadciśnienie tętnicze, przerost gruczołu sterczowego, zakażenia dróg moczowych i depresja. Do najczęstszych czynników należy spożycie alkoholu i palenie tytoniu, a także otyłość [1]. Większość tych stanów nasila rozwój miażdżycy, również w naczyniach tętniczych doprowadzających krew do ciał jamistych. Wykazano nawet korelację pomiędzy zaburzeniami erekcji a ryzykiem rozwoju choroby niedokrwiennej serca $[15,16]$.

U chorych na SSc dochodzi do zaburzeń erekcji bez rozwoju zmian miażdżycowych. U starszych chorych i u tych, u których SSc trwa stosunkowo długo wykrywa się pewne nasilenie miażdżycy [16, 17]. Niezależnie od złożoności zjawiska za tak zwany sclerodermic penis odpowiada zmieniony śródbłonek i włóknienie. Znajomość jednak innych czynników wpływających na zaburzenia erekcji jest niezbędną dla planowania terapii chorych, między innymi przez eliminację modyfikowalnych czynników ryzyka.

Zaburzenia erekcji zostały opisane po raz pierwszy u chorych na SSc w 1981 roku przez Lally'ego i Jimeneza [18]. Opisali oni 5 chorych na SSc, u których impotencja była pierwszym objawem choroby. W następnych latach ogłoszono kilka publikacji wskazujących na częste występowanie zaburzeń erekcji u pacjentów z omawianą chorobą $[19,20]$. Większość tych prac dotyczyła jednak małych populacji chorych, tym bardziej że SSc jest chorobą rzadką, a mężczyźni chorują w małym odsetku (ok. 6-7 kobiet przypada na 1 mężczyznę) [21]. Wszystkie te prace pokazują duży odsetek chorych ma SSc dotkniętych zaburzeniami erekcji (do 83\%). Największym opracowaniem jest praca Foocharoena i wsp. [22] zrealizowana w ramach grupy EUSTAR. Wśród przebadanych 130 mężczyzn chorujących na SSc tylko 17,7\% miało niezmienioną czynność erekcyjną. Poważne zaburzenia erekcji wykazano u 30,8\% badanych chorych. Nasilenie zmian erekcyjnych oceniano za pomocą International Index of Erectile Funcion-5 - badania kwestionariuszowego odznaczającego się czuło- 
ścią i swoistością wykrywania zaburzeń erekcji [22]. Zebranych chorych poddano analizie uwzględniającej współwystępowanie innych chorób (np. układowego nadciśnienia tętniczego, cukrzycy, palenia tytoniu, a także depresji, hyperprolaktynemii i nadmiernego spożywania alkoholu). Wykazano, że niektóre choroby współwystępujące i zażywanie niektórych leków istotnie zwiększa prawdopodobieństwo wystąpienia zaburzeń erekcji oraz ogólnie, im większa jest liczba chorób współwystępujących, tym większe jest ryzyko wystąpienia omawianych zaburzeń.

Interesujące jest też wykazanie związku występowania zaburzeń erekcji z niektórymi objawami lub zmianami stwierdzającymi u chorych, a należącymi do typowego obrazu klinicznego SSc. Wykazano zależność występowania zaburzeń erekcji od nasilenia zmian skórnych, zmniejszenia nasilonej pojemności oddechowej poniżej 80\% wartości należnych, występowaniem nadciśnienia w tętnicy płucnej (> $40 \mathrm{~mm} \mathrm{Hg}$ ), występowania przełomu nerkowego i dużej aktywności choroby. Nie stwierdzono związku zaburzeń wzwodu z występowaniem przeciwciał przeciwko topoizomerazie I (Scl-70), natomiast taki związek opisano w przypadku przeciwciał i antycentromerowych i skierowanych przeciwko polimerazie RNA III. Postać choroby (ograniczona, uogólniona), czas trwania jawnej choroby mierzony od wystąpienia objawu Raynauda lub innego objawu, a także takie objawy, jak owrzodzenia palców, tarcie ścięgniste, zaburzenia połykania czy włóknienie płuc oceniane w badaniach obrazowych nie miały związku z występowaniem zaburzeń erekcji. Nasilenie zaburzeń erekcji u chorych na SSc jest znaczne. Stosując wspomniany International Index of Erectile Dysfunctions-5 maksymalna liczba punktów wskazująca na brak zaburzeń to 25 . W omawianym badaniu mediana u 130 chorych na SSc to 13 , co odpowiada umiarkowanym zaburzeniom. Dla porównania w zbliżonej grupie wiekowej ogólnej populacji wynik średni to 22 [23] i tylko $1,3 \%$ mężczyzn cierpi na ciężkie zaburzenia erekcji. Wykazano również, że u chorych na SSc zaburzenia erekcji są częstsze niż w porównywalnej grupie chorych na reumatoidalne zapalenie stawów [24].

Ogólnie, przebadanie 130 chorych pokazuje, że mimo zróżnicowanego obrazu klinicznego i przebiegu SSc, większa aktywność choroby i jej nasilony przebieg sprzyja występowaniu zaburzeń erekcji. Ze względu na małe liczby chorych przy podziale na podgrupy mimo obserwowanej tendencji zmian nie uzyskano znamienności statystycznej pozwalającej na wysunięcie jednoznacznych wniosków. Tak było w przypadku czasu trwania objawu Raynauda. Mimo tych niedoskonałości, to największe badanie omawianego zagadnienia pokazuje, że zaburzenia erekcji wydają się łączyć z innymi objawami lub zmianami wynikłymi z rozwoju zaburzeń naczyniowych.

\section{BADANIA CZYNNOŚCIOWE UKŁADU NACZYNIOWEGO U CHORYCH NA TWARDZINE UKŁADOWA Z ZABURZENIAMI EREKCJI}

Ocena zaburzeń erekcji opiera się na subiektywnych odczuciach chorego, ale często wymaga dodatkowych badań pracownianych. Próby czynnościowe mogą dotyczyć bezpośrednio stanu członka lub być oceną ogólną stanu naczyń chorego.

Zajęcie układu naczyniowego może wyrażać się tętniczym nadciśnieniem płucnym, które koreluje z zaburzeniami erekcji [22]. Podobnie dodatnią korelację wykazano pomiędzy zaburzeniami przepływu krwi w tętnicach prącia i tętnicach palców oraz tętnicach nerkowych [25-27]. Podobnie wykazano zależność zmian w mikrokrążeniu stwierdzonych kapilaroskopowo z zaburzeniami erekcji, ale wykrycie zmian kapilaroskopowych nie pozwalało na przewidywanie wystąpienia zaburzeń erekcji [28].

Najczęściej wykonywanym badaniem jest ultrasonograficzna ocena przepływu krwi w ciałach jamistych. Bada się również termograficzne ciepłotę skóry prącia [29, 30]. Można oceniać zmiany obwodu członka u podstawy i żołędzi. W badaniu tym, możliwym do przeprowadzenia całodobowo u chorego przebywającego w domu ocenia się nocne i poranne wzwody, niezależne od pobudzenia seksualnego. Inwazyjny charakter ma ocena wzwodu po iniekcji prostaglandyny $\mathrm{E}_{1}$. Jest ona stosowana także przed określeniem ewentualnych korelacji kształtu członka zmienionych przez włóknienie. Rzadko wykonuje się arteriografię naczyń prącia [4].

Gigante i wsp. [31] wykazali zaburzony stosunek śródbłonkowego naczyniowego czynnika wzrostu (VEGF, vascular endothelial growth factor) do endostatyn u pacjentów z SSc i zaburzeniami erekcji, sugerując tym samym rolę regulacji angiogenezy w patogenezie tej choroby (podobnie jak i innych zapalnych chorób reumatycznych) [32]. Jak dotychczas badanie to nie znalazło zastosowania w praktyce klinicznej. 


\section{POSTEPOWANIE DIAGNOSTYCZNE Z CHORYM NA TWARDZINE UKŁADOWA I ZABURZENIAMI EREKCJI}

Postępowanie lekarskie z chorym na SSc i zaburzeniami erekcji ma charakter wybitnie złożony. Musi ona obejmować następujące grupy zagadnień: 1) zespół badań ogólnych wynikających z choroby podstawowej; 2) ocenę zaburzeń erekcji; 3) ocenę innych chorób lub czynników ryzyka mogących wpływać na stopień rozwoju waskulopatii.

W większości przypadków chory z zaburzeniami erekcji posiada już komplet badań pozwalających na rozpoznanie i ocenę zaawansowania zmian narządowych, w tym zmian bezpośrednio związanych z zajęciem naczyń. Istotne jest zapoznanie się z tymi wynikami i uzupełnienie badań niewykonanych lub nieaktualnych.

Reumatolog powinien pozyskać zaufanie chorego tak, aby zebrać w miarę pełny wywiad dotyczący zaburzeń erekcji. Łączy się z tym wywiad i badanie chorób towarzyszących. Przyjmuje się, że głównymi czynnikami odpowiedzialnymi za rozwój zaburzeń erekcji u chorych na SSc są zmiany naczyniowe i włóknienie, a w małym jedynie stopniu depresja, ale nie można w przypadku konkretnego chorego odrzucić a priori innych nietypowych lub niezwiązanych z SSc chorób lub zmian wpływających na wystąpienie zaburzeń erekcji. Należą do nich zmiany neurologiczne, zarówno obwodowe, jak i ośrodkowe, stany po urazach lub zaburzeniach rozwojowych kręgosłupa, choroby demielinizacyjne (niektóre mogą towarzyszyć chorobom autoimmunologicznym).

Zaburzenia hormonalne u chorych na SSc nie były opisywane jako przyczyna zaburzeń erekcji. Dla pełnej oceny stany chorego wskazana jest ocena, czy nie doszło do wtórnego hypogonadyzmu lub innych zaburzeń hormonalnych. Hyperprolaktynemia jest częstym zjawiskiem w chorobach autoimmunologicznych i była też opisana u chorych na SSc [33]. Niedoczynność tarczycy jest częsta w SSc, ale nie zawsze jest rozpoznawana.

Wcześniej wymieniono liczne choroby (w tym metaboliczne) mogące powodować lub nasilać zaburzenia erekcji [34]. Palenie tytoniu (wyjątkowo szkodliwe ze względu na obkurczanie naczyń u chorych na SSc) oraz spożywanie alkoholu są częstym czynnikiem odpowiedzialnym za zaburzenia erekcji, zarówno w populacji ogólnej, jak i u chorych na SSc.

Duża liczba leków może upośledzić funkcje seksualne i o tym należy pamiętać w ocenie chorych. Przykładami takich leków są diuretyki tiazydowe, spironolaktony, leki $\beta$-adrenolityczne, antagoniści receptorów $\mathrm{H}_{2}$, niektóre antydepresanty oraz cyklofosfamid.

Trzeba także wziąć pod uwagę wiek chorego, który w populacji ogólnej łączy się ze zmniejszeniem sprawności wzwodu członka. $\mathrm{Z}$ tym łączą się zmiany miażdżycowe i stosunkowo dobrze opisane czynniki wpływające na ich rozwój. Niezbędna jest ocena dróg moczowych. Objawy ze strony dolnych dróg moczowych, takie jak cechy pęcherza nadreaktywnego, nietrzymanie moczu oraz dysuria często towarzyszące zaburzeniom erekcji u chorych na SSc [35].

W ostatnim etapie badania reumatolog zajmujący się pacjentem z SSc i zaburzeniami erekcji powinien uwzględnić możliwe do wykonania badania naczyniowe (o ile nie były przeprowadzone w ramach ogólnej oceny choroby), takie jak ultrasonograficzna ocena przepływu krwi w prąciu.

\section{LECZENIE}

Leczenie zaburzeń erekcji u chorych na SSc jest trudne i często nieskuteczne. Problem jest też stosunkowo słabo zbadany. Za wyjściowe postępowanie przyjmuje się analizę oraz eliminację lub korekcję wszystkich modyfikowalnych czynników ze strony stylu życia, chorób towarzyszących i zażywanych leków.

Farmakoterapia zaburzeń erekcji opiera się na stosowaniu inhibitorów fosfodiesterazy-5. Leki te zwiększają stężenie cGMP, które sprzyja relaksacji mięśni gładkich, ułatwiając napływ krwi do ciał jamistych. Leki te ułatwiają erekcję, ale jej nie wywołują, niezbędna jest stymulacja seksualna. Dostępnych jest kilka leków z wymienionej grupy, które różnią się czasem działania, chociaż przyjmuje się, że skuteczność ich jest zbliżona. Stosowanie inhibitorów fosfodiestrazy-5 u chorych na SSc było przedmiotem tylko pojedynczych prac. Wykazano, że stałe podawanie leku jest skuteczniejsze niż podawanie na życzenie [4]. Stałe podawanie łączy się poprawą obiektywnych wskaźników ukrwienia prącia oraz wskaźników stanu śródbłonka [36]. Sugerowano również większą efektywność tadalafilu niż sildenafilu [12]. Interesujące jest, że inhibitory fosfodiesterazy-5 są lekami stosowanymi u chorych na $\mathrm{SSc}$ w celu leczenia nadciśnienia płucnego. $\mathrm{Na}$ ile $u$ tych chorych dochodzi do zmniejszenia zaburzeń erekcji, nie wiadomo. 
Trudniejsze technicznie jest podawanie pochodnych prostacykliny. Leki te wstrzykuje się do ciał jamistych. Czynione są też próby stosowania analogów prostacykliny w postaci wkładek docewkowych lub podawania leku miejscowo jako maść [37].

U chorych, u których wspomniane leki nie są skuteczne zaleca się próżniowe pompki powodujące napływ krwi do ciał jamistych. Są one dość powszechnie stosowane u chorych z zaburzeniami erekcji z innych przyczyn (np. cukrzycy).

Nadmuchiwane protezy ciał jamistych rzadko są implantowane $\mathrm{u}$ chorych na SSc. Wynika to z faktu, że ich wszczepienie wymaga wycięcia zwłókniałych tkanek, co może być trudnym technicznie zabiegiem [4].

Wspomnieć należy o próbach terapii regenerującej śródbłonek naczyń jamistych, transplantacji komórek mezenchymalnych, komórek macierzystych oraz komórek tłuszczowych. Inną drogą poszukiwań jest terapia genowa ukierunkowana na wytworzone przez komórki śródbłonka tlenku azotu lub VEGF.
Prace te nie wyszły jak dotąd poza badania eksperymentalne [38].

\section{PODSUMOWANIE}

O zaburzeniach erekcji u chorych na SSc ciągle niewiele wiadomo, poza tym że występują często. Jak wspomniano, wynika to ze stosunkowo rzadkiego rozpoznawania SSc u mężczyzn, a także pomijania tego tematu przy zbieraniu wywiadu. Może to wynikać $\mathrm{z}$ niedostatecznego przygotowania reumatologa do analizy zagadnień seksuologicznych. Zaburzenia erekcji nie są czynnikiem samym w sobie zagrażającym życiu chorego, ale często korelują z rozwojem innych zmian naczyniowych. Mają jednak duże znaczenie dla jakości życia chorych, tym bardziej że ujawniają się najczęściej od początku jawnej klinicznie choroby. Mimo ograniczonych możliwości terapeutycznych istotne wydaje się poszerzenie znajomości tematu, co pozwoli w niektórych przypadkach pomóc chorym, a zawsze uczyni działania reumatologa pełniejsze i bardziej ukierunkowane na chorego niż chorobę. 